\title{
DETERMINAN DANA PIHAK KETIGA DAN HUBUNGANNYA TERHADAP KREDIT BANK UMUM (STUDI KASUS PROVINSI JAMBI)
}

\author{
Andri Devita \\ Ekonomi Pembangunan, STIE Muhammadiyah Jambi \\ email : andridevita86@yahoo.com
}

\begin{abstract}
This study uses secondary data collected by research object in Jambi Province in the form of data of third party fund of commercial banks, interest rate and total credit data and economic growth sourced from Bank Indonesia as well as and Central Bureau of Statistics (BPS). Data were collected during the period 2004 to 2015. Objectives of the study 1). analyze the factors that influence the Third Party Fund (DPK) of Jambi Province. 2). analyzing the relationship of third party funds (DPK) to the amount of credit disbursed by commercial banks in Jambi Province. The analytical tool used is focusing on multiple linear regression analysis in time series and correlation person through with the help of software SPSS series 21.0. Based on the discussion of data analysis results in this study, can be drawn conclusion as follows: 1). bank interest rate variable negatively and insignificant to third party funds Jambi Province, while the number of banks and economic growth significantly influence third party funds Jambi Province during the period 2004-2015 with R-square 99.3\%. 2). the relationship between third party funds and bank credit distribution is very strong with correlation value of $0.994 \times 100 \%$ $=99.40 \%$.
\end{abstract}

Keywords: Bank Interest Rate, Third Party Funds, Economic Growth, and Bank Loans

\section{PENDAHULUAN}

Lembaga keuangan memiliki peran yang sangat penting dalam pengembangan dan pertumbuhan kondisi ekonomi suatu negara. Lembaga keuangan yang terlibat dalam suatu pembiayaan pembangunan ekonomi dibagi dua yaitu Lembaga Keuangan Bank dan Lembaga Keuangan Bukan Bank. Bank dibedakan menjadi dua jenis yaitu bank umum dan bank perkreditan rakyat (Adisetiawan, 2012). Perbankan juga memilik peranan yang sangat strategis dalam menunjang berjalannya roda perekonomian dan pembangunan nasional mengingat fungsinya sebagai lembaga intermediasi, penyelenggaraan transaksi pembayaran, serta alat transmisi kebijakan moneter.(Rihlah 2010).

Kegiatan utama perbankan dalam menjalankan fungsi intermediasinya adalah penyaluran kredit. Penyaluran kredit merupakan penyaluran dana dari pihak kelebihan dana kepada pihak yang memerlukan dana. Penyaluran dana tersebut didasarkan pada kepercayaan yang diberikan oleh pemilik dana kepada pengguna dana. Penyaluran kredit tersebut dapat membantu masyarakat dalam melakukan berbagai kegiatan ekonominya.(Hardi 2012)

Disamping itu peranan perbankan sangat mempengaruhi kegiatan ekonomi suatu negara, bank dapat dikatakan sebagai darahnya perekonomian suatu negara. Oleh karena itu kemajuan suatu bank suatu negara dapat pula dijadikan ukuran kemajuan negara yang bersangkutan. Semakin maju suatu negara, maka semakin besar peranan perbankan dalam mengendalikan negara tersebut (Kasmir, 2010). Pentingnya fungsi dan peran sektor perbankan dalam pertumbuhan ekonomi, 
sehingga lembaga keuangan yang berperan adalah bank umum (commercial bank). Bank umum memiliki peranan yang sangat penting dalam menggerakkan roda perekonomian nasional, alasannya karena kurang lebih $95 \%$ dana pihak ketiga dikelola oleh bank.

Menurut Mardiasmo (2004) pertumbuhan ekonomi daerah secara langsung akan mempengaruhi pertumbuhan perbankan daerah. Jika perekonomian masyarakat daerah lesu, maka perbankan di daerah tersebut juga akan mengalami kelesuan, demikian pula sebaliknya sehingga perbankan di daerah harus benarbenar mengetahui kondisi makro ekonomi daerah. Informasi mengenai kondisi makro ekonomi daerah tersebut sangat penting untuk pengambilan keputusan mengenai kebijakan pemberian kredit, penetapan suku bunga dan menilai produkproduk perbankan. Kondisi makro yang perlu diperhatikan seperti: pertumbuhan ekonomi daerah, PDRB, perekonomian ekonomi sektoral, laju inflasi daerah, arus investasi daerah, kependudukan dan APBD.

Pendapatan bank sangat didominasi oleh penyaluran kredit karena keuntungan utama bank diperoleh dari selisih bunga simpanan dan pinjaman. Usaha kredit perbankan ini sangat membantu para pelaku usaha dalam menjalankan dan mengembangkan usahanya karena bank dapat memberikan pinjaman kredit berupa kredit investasi atau kredit modal kerja guna menambah modal usaha bagi para pelaku usaha tersebut. Untuk mengambil keputusan mengenai kebijakan kreditnya, maka pihak perbankan harus menganalisis kondisi makro daerahnya seperti PDRB dan Inflasi, selain itu sumber dana yang diperoleh dari dana pihak ketiga juga perlu dianalisis agar kredit perbankan dapat disalurkan secara optimal.

Pentingnya simpanan nasabah dengan kata lain dana pihak ketiga mengindikasikan bahwa aktivitas yang dilakukan bank membutuhkan dana masyarakat (Kuncoro dan Suhardjono, 2011) salah satunya adalah menyalurkan kredit yang menjadi sumber utama pendapatan bank umum. Dengan meningkatnya dana pihak ketiga yang berhasil dihimpun akan semakin banyak kredit yang dapat disalurkan. Upaya mempercepat pembangunan tidak terlepas dari peranan pihak perbankan dalam menyalurkan dana yang di kelolanya untuk pembayaran pembangunan. Kredit yang di berikan oleh pihak perbankan terutama kredit produktif bertujuan agar pihak debitur dapat mengembangkan usahanya lebih lanjut. Sehingga dapat mengerakkan roda perekonomian secara keseluruhan. Selama kurun waktu 2010-2015 jumlah kredit produktif yang diberikan Bank Umum dan BPR kepada pihak debitur menunjukkan perkembangan jumlah kredit di Provinsi Jambi dapat dilihat kredit yang diberikan Bank Umum dan BPR di Provinsi Jambi menunjukkan kecenderungan yang terus meningkat secara ratarata selama periode 2010-2015 laju pertumbuhan kredit Bank Umum dan BPR kepada debitur adalah sebesar 27,37\%.

Apabila dilihat dari kelompok bank di Provinsi Jambi, yaitu bank umum dengan jumlah kredit yang diberikan oleh bank umum lebih besar dibandingkan dengan pinjaman yang diberikan oleh pihak BPR. Peningkatan jumlah kredit yang disalurkan oleh Bank Umum dan BPR Provinsi Jambi tersebut tidak terlepas dari kemampuan pihak perbankan itu sendiri dalam menghimpun dana pihak ketiga. Kemampuan menghimpun dana dari debitur tersebut pada akhirnya juga akan mempengaruhi besar kecilnya kemampuan dalam memberikan kredit perbankan. Secara keseluruhan kredit yang diberikan pihak perbankan Provinsi Jambi menunjukkan kecenderungan yang terus meningkat. Dimana kredit yang 
diberikan oleh bank umum memegang persentase yang lebih besar dibandingkan kelompok Bank Perkreditan Rakyat (BPR).

Selain itu, Bank Indonesia selaku otoritas moneter terus melakukan intervensi yaitu campur tangan dalam mengatur perekonomian yang bertujuan untuk meningkatkan efisiensi suatu sektor tertentu melalui pengeluaran kebijakan moneter dan fiskal. Namun upaya tersebut belum menunjukkan hasil yang diharapkan. Kemerosotan dan gejolak nilai rupiah terus berlanjut yang berdampak pada inflasi, sementara kepercayaan investor terhadap kemampuan pengelolaan dan prospek ekonomi semakin berkurang.

\section{Tinjauan Pustaka}

\section{Konsep Bank}

Bank adalah badan usaha yang kekayaannya terutama dalam bentuk asset keuangan (financial assets) serta bermotifkan profit dan juga sosial, jadi bukan hanya keuntungan saja (Hasibuan, 2005). Menurut Dictionary of Banking and financial service by Jerry Rosenberg, bank adalah lembaga yang menerima simpanan giro, deposito dan membayar atas dasar dokumen yang ditarik pada orang atau lembaga tertentu, mendiskonto surat berharga, dan menanamkan dananya dalam surat berharga (Taswan, 2006); (Adisetiawan, 2012).

Berdasarkan Pernyataan Standar Akuntansi Keuangan (PSAK) No. 31, Bank adalah suatu lembaga yang berperan sebagai perantara keuangan (Financial Intermediary) antara pihak-pihak yang memiliki kelebihan dana (Surplus Unit) dengan pihak-pihak yang memerlukan dana (Deficit Unit), serta sebagai lembaga yang berfungsi memperlancar lalu lintas pembayaran. Sedangkan menurut Kuncoro (2004), definisi dari bank adalah lembaga keuangan yang usaha pokoknya adalah menghimpun dana dan menyalurkan kembali dana tersebut ke masyarakat dalam bentuk kredit serta memberikan jasa-jasa dalam lalu lintas pembayaran dan peredaran uang. Oleh karena itu, dalam melakukan kegiatan usahanya sehari-hari bank harus mempunyai dana agar dapat memberikan kredit kepada masyarakat. Dana tersebut dapat diperoleh dari pemilik bank (pemegang saham), pemerintah, bank Indonesia, pihak-pihak di luar negeri, maupun masyarakat dalam negeri.

Dana dari pemilik bank berupa setoran modal yang dilakukan pada saat pendirian bank. Dana dari pemerintah diperoleh apabila bank yang bersangkutan ditunjuk oleh pemerintah untuk menyalurkan dana-dana bantuan yang berkaitan dengan pembiayaan proyek-proyek pemerintah, misalnya Proyek Inpres Desa Tertinggal. Sebelum dana diteruskan kepada penerima, bank dapat menggunakan dana tersebut untuk mendapatkan keuntungan, misalnya dipinjamkan dalam bentuk pinjaman antar bank (Interbank Call Money) berjangka 1 hari hingga 1 minggu. Keuntungan bank diperoleh dari selisih antara harga jual dan harga beli dana tersebut setelah dikurangi dengan biaya operasional. Dana-dana masyarakat ini dihimpun oleh bank dengan menggunakan instrumen produk simpanan yang terdiri dari Giro, Deposito dan Tabungan.

\section{Peran Bank}

Dalam menjalankan kegiatannya bank mempunyai peran penting dalam sistem keuangan, yaitu: (Adisetiawan, 2012)

\section{Pengalihan Aset (Asset Transmutation)}


Yaitu pengalihan dana atau aset dari unit surplus ke unit devisit. Dimana sumber dana yang diberikan pada pihak peminjam berasal pemilik dana yaitu unit surplus yang jangka waktunya dapat diatur sesuai dengan keinginan pemilik dana. Dalam hal ini bank berperan sebagai pangalih aset yang likuid dari unit surplus (lender) kepada unit defisit (borrower).

\section{Transaksi (Transaction)}

Bank memberikan berbagai kemudahan kepada pelaku ekonomi untuk melakukan transaksi. Dalam ekonomi modern, transaksi barang dan jasa tidak pernah terlepas dari transaksi keuangan. Untuk itu produk-produk yang dikeluarkan oleh bank (giro, tabungan, depsito, saham dan sebagainya) merupakan pengganti uang dan dapat digunakan sebagai alat pembayaran.

\section{Likuiditas (Liquidity)}

Unit surplus dapat menempatkan dana yang dimilikinya dalam bentuk produkproduk berupa giro, tabungan, deposito, dan sebagainya. Produk-produk tersebut masing-masing mempunyai tingkat likuiditas yang berbeda-beda. Untuk kepentingan likuiditas para pemilik dana dapat menempatkan dananya sesuai dengan kebutuhan dan kepentingannya. Dengan demikian bank memberikan fasilitas pengelolaan likuiditas kepada pihak yang mengalami surplus likuiditas dan menyalurkannya kepada pihak yang mengalami kekurangan likuiditas.

\section{Efisiensi (Efficiency)}

Peranan bank sebagai broker adalah menemukan peminjam dan pengguna modal tanpa mengubah produknya. Disini bank hanya memperlancar dan mempertemukan pihak-pihak yang saling membutuhkan. Adanya informasi yang tidak simetris (asymmetric information) antara peminjam dan investor menimbulkan masalah insentif. Peran bank menjadi penting untuk memecahkan masalah insentif tersebut. Untuk itu jelas peran bank dalam hal ini yaitu menjembatani dua pihak yang saling berkepentingan untuk menyamakan informasi yang tidak sempurna, sehingga terjadi efisiensi biaya ekonomi.

\section{Fungsi dan Usaha Bank Umum}

Bank umum sebagai lembaga intermediasi keuangan memberikan jasa-jasa keuangan baik kepada unit surplus maupun kepada unit defisit. Bank melaksanakan beberapa tungsi dasar. Fungsi Pokok Bank Umum Bank umum memiliki fungsi pokok sebagai berikut : (Adisetiawan, 2012)

1. Menyediakan mekanisme dan alat pembayaran yang lebih efisien dalam kegiatan ekonomi

2. Menciptakan uang

3. Menghimpun dana dan menyalurkannya kepada masyarakat

4. Menawarkan jasa-jasa keuangan lain. Usaha Bank Kegiatan usaha yang dapat dilakukan oleh Bank umum menurut UU No. 10 Tahun 1998 tentang Perbankan adalah sebagai berikut:

a. Menghimpun dana dari masyarakat

b. Memberikan kredit

c. Menerbitkan surat pengakuan hutang

d. Membeli, menjual atau menjamin atas risiko sendiri maupun untuk kepentingan dan atas perintah nasabahnya: 


\section{Dana Pihak Ketiga}

Dalam rangka mendukung aktivitas operasional bank yang kaitannya dengan penyaluran dana, bank perlu memperoleh sumber dana yang cukup untuk mendukung kegiatan tersebut. Salah satunya adalah dana masyarakat yang merupakan mayoritas dari seluruh dana yang dihimpun oleh bank dalam kegiatan usaha sehari-hari (Kuncoro dan Suhardjono, 2011). Dengan kata lain, dana pihak ketiga berperan sebagai input dalam menyalurkan kredit.

Dana Pihak Ketiga merupakan dana simpanan masyarakat dalam bentuk giro, tabungan dan deposito. Dengan sumber dana ini, bank memanfaatkannya sebagai ladang yang dapat menghasilkan pendapatan bagi bank yang salah satunya adalah menyalurkan kredit. Ismail (2010) mengatakan sumber dana yang berasal dari pihak ketiga ini antara lain:

a. Giro

Giro merupakan simpanan yang berasal dari dana pihak ketiga yang penarikannya dapat dilakukan sewaktu-waktu dengan menggunakan sarana penarikan berupa cek, bilyet giro, dan sarana penarikan lainnya. Giro sangat bermanfaat bagi masyarakat dalam melakukan transaksi bisnisnya, karena memberikan kemudahan tersendiri. Memiliki rekening giro, sama dengan memiliki uang tunai. Karena sifat rekening giro dapat dicairkan setiap saat.

b. Tabungan

Menurut Undang-Undang No. 10 Tahun 1998 mengenai perbankan, bahwa tabungan adalah simpanan yang penarikannya hanya dapat dilakukan menurut syarat tertentu yang telah disepakati, tetapi tidak dapat ditarik dengan cek, bilyet giro atau alat lainnya yang dapat dipersamakan dengan itu.

c. Deposito

Deposito merupakan jenis simpanan yang penarikannya hanya dapat dilakukan sesuai dengan jangka waktu yang telah diperjanjikan antara bank dan nasabah. Deposito dibedakan menjadi tiga jenis, yaitu: deposito berjangka, sertifikat deposito, dan deposito on call.

Deposito berjangka merupakan simpanan berjangka yang dapat dicairkan sesuai dengan jangka waktu yang disepakati. Pemegang deposito berjangka akan mendapat bilyet deposito sebagai bukti hak kepemilikannya. Sertifikat Deposito adalah simpanan dalam bentuk deposito yang sertifikat bukti penyimpanannya dapat dipindahtangankan atau diperjualbelikan. Sedangkan Deposit on Call adalah jenis simpanan berjangka yang penarikannya perlu memberitahukan terlebih dahulu kepada bank penerbit deposit on call. Deposit on Call diterbitkan atas nama, dan tidak dapat diperjualbelikan. Bunga dibayar pada saat pencairan.

\section{Konsep Kredit}

Kata kredit berasal dari bahasa latin yaitu "credere", yang artinya percaya atau to believe atau to trust. Oleh karena itu, dasar pemikiran persetujuan pemberian kredit oleh bank pada seseorang atau badan usaha adalah kepercayaan. Bila dikaitkan dengan kegiatan usaha, kredit berarti suatu kegiatan memberikan nilai ekonomi (economi value) kepada seseorang atau badan usaha yang berlandaskan kepercayaan saat itu, bahwa nilai ekonomi yang sama akan dikembalikan pada kreditur (bank) setelah jangka waktu sesuai dengan kesepakatan yamg sudah disetujui antara kreditur dan debitur. 
Menurut Eddie Rinaldy (2009) kredit adalah penyediaan uang atau tagihan yang dapat dipersamakan dengan itu, berdasarkan persetujuan atau kesepakatan pinjam meminjam antara bank dan pihak lain yang mewajibkan pihak peminjam (debitur) untuk melunasi hutangnya setelah jangka waktu tertentu dengan jumlah bunga, imbalan atau pembagian hasil keuntungan . Termasuk dalam pengertian kredit dalam restrukturisasi, dan pembelian surat berharga debitur yang dilengkapi dengan Note Purchase Agreement (NPA).

Disisi lain Suyatno dkk (2003) mengartikan kredit sebagai kepercayaan seseorang atau badan yang memberikan kredit yang percaya bahwa penerima kredit dimana yang akan datang akan sanggup memnuhi segala sesuatu yang sudah dijanjikan. Sastradipoera (2004) menyebutkan, kredit adalah penyediaan uang atau tagihan (yang disamakan dengan uang) berdasarkan kesepakatan pinjam meminjam antara bank dan pihak lain yang dalam hal ini peminjam berkewajiban melunasi kewajibannya setelah jangka waktu tertentu dengan (biasanya) sejumlah bunga yang ditetapkan lebih dahulu.

Kasmir (2008) mengemukakan tujuan pemberian suatu kredit, yaitu:

\section{Untuk mencari keuntungan.}

Bertujuan untuk memperoleh hasil dari pemberian kredit tersebut. Hasil tersebut terutama dalam bentuk bunga yang diterima oleh bank sebagai balas jasa dan biaya administrasi kredit yang dibebankan kepada nasabah.

2. Untuk meningkatkan usaha nasabah debitur.

Untuk membantu usaha nasabah yang memerlukan dana, baik dana investasi maupun dana untuk modal kerja. Dengan dana tersebut, maka pihak debitur akan dapat mengembangkan dan memperluas usahanya.

3. Untuk membantu Pemerintah.

Bahwa, dengan banyaknya kredit yang disalurkan oleh bank-bank, hal ini berarti dapat meningkatkan pembangunan disegala sektor, khususnya disektor ekonomi.

Dari beberapa rumusan tersebut diatas maka kredit haruslah memiliki unsur waktu pengembalian dan harus memiliki kredibilitas. Dengan demikian seorang yang mendapatkan kredit haruslah memiliki kemampuan mengembalikan pinjaman tersebut dan memiliki kredibilitas yang baik. Sedangkan dalam penelitian ini kredit yang akan dibahas adalah kredit bank Umum. Pengertian tentang kredit perbankan seperti yang tercantum dalam Undang-Undang pokok perbankan nomor 7 tahun 1992, bahwa kredit adalah penyediaan uang atau tagihan yang dapat dipersamakan dengan itu, berdasarkan persetujuan dan kesepakatan pinjam meminjam antara bank dengan pihak lain yang mewajibkan pihak peminjam untuk melunasi hutangnya setelah jangka waktu tertentu dengan jumlah bunga, imbalan atau pembagian hasil keuntungan.

Menurut Undang-undang pokok perbankan No. 10 Tahun 1998 ditegaskan bahwa "Kredit yang diberikan oleh Bank mengandung resiko, sehingga dalam pelaksanaannya bank harus memperhatikan asas-asas perkreditan yang sehat" adapun pedoman dalam pemberian kredit tersebut sekurang-kurangnya memuat dan mengatur hal-hal pokok sebagai berikut: Prinsip kehati-hatian dalam perkreditan; Organisasi dan manajemen perkreditan; Kebijaksanaan persetujuan pemberian kredit; Dokumentasi dan administrasi kredit; Pengawasan kredit; dan Penyelesaian kredit bermasalah Menurut Kuncoro (2004) proses pemberian kredit terdiri dari 3 tahap, yaitu tahap kegiatan prakarsa dan analisis kredit, tahap rekomendasi kredit dan tahap putusan kredit. Oleh karena itu pejabat dalam 
perkreditan juga dibedakan menjadi 3 fungsi, yaitu pejabat pemrakarsa/penganalisis kredit, pejabat perkomendasi dan pejabat pemutus kredit.

\section{Kredit Bank}

Menurut Undang-undang Republik Indonesia Nomor 10 tahun 1998 (pasal 1 ayat 11) ; kredit adalah penyediaan uang atau tagihan yang dapat dipersamakan dengan itu, berdasarkan persetujuan atau kesepakatan pinjam-meminjam antara bank dengan pihak lain yang mewajibkan pihak peminjam untuk melunasi utangnya setelah jangka waktu tertentu dengan pemberian bunga. Berdasarkan pengertian kredit yang telah ditetapkan oleh undang-undang sebagaimana yang disebut diatas, tidak semua kegiatan pinjam meminjam dapat dikategorikan kredit bagi perbankan. Suatu pinjam meminjam uang akan digolongkan sebagai kredit perbankan sepanjang memenuhi unsur-unsur yaitu:

1. Adanya penyediaan uang atau tagihan yang dapat dipersamakan dengan penyediaan uang. Adapun pihak yang melakukan penyediaan uang tersebut adalah perbankan. Bank adalah penyedia dana tersebut yang kemudian disebut dengan nama kredit atau plafond kredit.

2. Adanya persetujuan atau kesepakatan pinjam meminjam antara bank dengan pihak lain. Persetujuan atau kesepakatan pinjam meminjam merupakan dasar dari penyediaan uang atau tagihan tersebut. Persetujuan atau kesepakatan pinjam meminjam dibuat oleh bank dengan pihak debitur yang diwujudkan dalam suatu perjanjian kredit, akad kredit dan sebagainya.

3. Adanya kewajiban melunasi utang. Pinjam meminjam uang adalah suatu utang dimana pihak peminjam wajib melunasinya sesuai dengan jadwal pembayaran yang telah disepakati sesuai dengan ketentuan dalam perjanjian kredit tersebut.

4. Adanya jangka waktu tertentu. Pemberian kredit terkait dengan suatu jangka waktu tertentu yang ditetapkan dalam perjanjian. Jangka waktu yang ditetapkan merupakan batas waktu kewajiban bank untuk menyediakan dana pinjaman dan menunjukkan kesemptaan bagi debitur untu melunasinya.

5. Adanya pemberian bunga kredit, terhadap suatu kredit sebagai bentuk peminjaman uang ditetapkan adanya pemberian bunga. Bank menetapkan suku bunga atas pinjaman uang yang telah diberikannya. Suku bunga merupakan harga atas uang yang dipinjamkan dan disetujui bank kepada debitur. Suku bunga tersebut terkadang juga disebut sebagai balas jasa atas penggunaan uang bank oleh debitur. Sepanjang terhadap bunga kredit dalam perjanjian yang dilakukan pembayarannya oleh debitur maka pendapatan bunga tersebut akan menjadi salah satu sumber pendapatan yang utama bagi bank.

Berdasarkan uraian-uraian tersebut di atas, Kasmir (2008) mengemukakan unsur-unsur yang terkandung dalam pemberian suatu kredit, antara lain:

1. Kepercayaan; yaitu adanya keyakinan dari pihak bank atas prestasi yang diberikannya kepada nasabah peminjam dana yang akan dilunasinya sesuai dengan waktu yang telah diperjanjikan.

2. Kesepakatan; disamping unsur kepercayaan didalam kredit juga mengandung unsur kesepakatan antara bank dengan nasabah. Kesepakatan ini dituangkan dalam suatu perjanjian dimana masing-masing pihak menandatangani hak dan kewajibannya masing-masing.

3. Jangka Waktu; setiap kredit yang diberikan memiliki jangka waktu tertentu, jangka waktu ini mencangkup masa pengembalikan kredit yang telah 
disepakati. Jangka waktu tersebut dapat berbentuk jangka pendek, jangka menengah atau jangka panjang.

4. Resiko; adanya suatu tenggang waktu pengembalian akan menyebabkan suatu resiko tidak tertagihnya atau macet pemberian kredit. Semakin panjang suatu kredit semakin besar resikonya. Resiko ini menjadi tanggungan bank baik resiko yang disengaja oleh nasabah yang lalai maupun resiko yang tidak disengaja.

5. Balas Jasa; merupakan keuntungan atas pemberian suatu kredit. Balas jasa dalam bentuk bunga dan biaya administrasi kredit merupakan keuntungan bank.

Menurut Kasmir (2008) bahwa secara umum jenis-jenis kredit dapat ditinjau dari berbagai sudut diantaranya ditinjau dari sudut kegunaan, yaitu:

1. Kredit konsumtif yaitu kredit yang diberikan kepada debitur untuk keperluan konsumsi seperti kredit profesi, kredit perumahan, kredit kendaraan bermotor, pembelian alat-alat rumah tangga, dan lain sebagainya.

2. Kredit produktif, yang terdiri dari kredit Investasi (yang dipergunakan untuk membeli barang modal atau barang-barang tahan lama seperti tanah, mesin, dan sebagainya) dan kredit modal kerja (digunakan untuk keperluan meningkatkan produksi dalam operasionalnya, seperti untuk membeli bahan baku, membayar gaji pegawai atau biaya-biaya lainnya yang berkaitan dengan proses produksi perusahaan).

Terdapat banyak jenis kredit yang di berikan oleh bank umum dan bank perkreditan rakyat maupun lembaga keuangan lainnya untuk masyarakat terdiri dari beberapa jenis yaitu :

\section{Dilihat Dari Segi Tujuan Pegunaannya}

a. Kredit Produktif

1) Kredit investasi

Yaitu kredit yang diberikan untuk pengadaan barang modal maupun jasa yang dimaksudkan untuk menghasilkan suatu barang atau jasa bagi usaha yang bersangkutan. Kredit ini diberikan kepada perusahaan yang baru akan berdiri untuk keperluan membangun pabrik baru.

2) Kredit modal kerja

Yaitu kredit yang diberikan untuk membiayai kebutuhan usaha, termasuk guna menutupi biaya produksi dalam rangka peningkatan produksi atau penjualan. Kredit ini diberikan kepada perusahaan yang telah berdiri, namun membutuhkan dana untuk meningkatkan produksi dalam operasionalnya. Misalnya dalam hal membayar gaji pegawai atau unutk membeli bahan baku.

b. Kredit Konsumtif

Adalah kredit yang diberikan digunakan untuk konsumsi secara pribadi. Dalam kredit ini tidak akan menembah barang atau jasa yang dihasilkan karena memang untuk digunakan atau dipakai aleh seseorang atau badan usaha.

\section{Dilihat Dari Segi Sektor Usaha}

a. Kredit Pertanian

Diberikan untuk membiayai sektor perkebunan atau pertanian rakyat.

b. Kredit Peternakan 
Diberikan untuk jangka pendek misalnya untuk peternakan ayam dan jangka panjang misalnya untuk kambing ataupun sapi.

c. Kredit Industri

Diberikan untuk membiayai industri kecil, menengah atau besar.

d. Kredit Perumahan

Diberikan untuk membiayai pembangunan atau pembelian rumah.

\section{Kredit Ditinjau Dari Segi Jangka Waktu}

a. Kredit Jangka Pendek

Yaitu suatu kredit yang diberikan tidak melebihi jangka waktu 1 tahun.

b. Kredit Jangka Menengah

Yaitu suatu kredit yang diberikan dengan jangka waktu $1-3$ tahun.

c. Kredit Jangka Panjang

Yaitu suatu kredit yang diberikan dengan jangka waktu lebih dari 3 tahun.

\section{Kredit Ditinjau Dari Segi Jaminannya}

a. Kredit Dengan Jaminan

Adalah suatu kredit yang diberikan dengan suatu jaminan, baik berupa barang/benda berwujud atau tidak berwujud, dan atau jaminan orang.

b. Kredit Tanpa Jaminan

Adalah suatu kredit yang diberikan tanpa jaminan baik berupa barang/benda berwujud atau tidak berwujud, dan atau jaminan orang.

\section{Tujuan Pemberian Kredit dan Pengaruhnya Bagi Perekonomian}

Tjoekam (1999) menjelaskan bahwa, perkreditan melibatkan beberapa pihak: kreditur (bank), debitur (penerima kredit), otorita moneter, dan bahkan masyarakat pada umumnya. Oleh karena itu, tujuan perkreditan berbeda-beda dan tergantung pada pihak-pihak tersebut.

1. Bagi Kreditur (Bank)

a. Perkreditan merupakan sumber utama pendapatannya.

b. Pemberian kredit merupakan perangsang pemasaran produk-produk lainnya dalam persaingan

c. Perkreditan merupakan instrumen penjaga likuiditas, solvabilitas dan profitabilitas bank.

2. Bagi Debitur

a. Kredit berfungsi sebagai sarana untuk membuat kegiatan usaha makin lancar dan performance (kinerja) usaha semakin baik dari pada sebelumnya.

b. Kredit meningkatkan minat berusaha dan keuntungan sebagai jaminan kelanjutan kehidupan perusahaan.

c. Kredit memperluas kesempatan berusaha dan bekerja dalam perusahaan.

3. Bagi Otorita :

a. Kredit berfungsi untuk menciptakan kesempatan berusaha dan kesempatan kerja yang memperluas sumber pendapatan dan kemungkinan membuka sumber- sumber pendapatan negara.

b. Kredit berfungsi sebagai instrument untuk ikut serta meningkatkan mutu manajemen dunia usaha, sehingga terjadi efisiensi dan mengurangi pemborosan di semua lini.

4. Bagi Masyarakat: 
a. Kredit dapat menimbulkan backward dan forward linkage dalam kehidupan perekonomian.

b. Kredit mengurangi pengangguran, karena membuka peluang berusaha, bekerja dan pemerataan pendapatan.

c. Kredit meningkatkan fungsi pasar, karena ada peningkatan daya beli (social buying power).

Seandainya otoritas moneter tidak melakukan kebijakan moneter melalui pengawasan terhadap kegiatan perkreditan perbankan, maka akan membuat perekonomian memang tumbuh tapi dalam posisi tingkat harga barang dan bunga kredit meningkat secara terus menerus, yang pada akhirnya justru akan mempersulit perekonomian makro secara keseluruhan.

\section{Hipotesis}

Berdasarkan pada rumusan masalah dan pertanyaan penelitian di atas, maka hipotesis yang dapat diambil dapat dirumuskan sebagai berikut :

1. Diduga suku bunga, jumlah bank dan pertumbuhan ekonomi berpengaruh positif terhadap peningkatan dana pihak ketiga di Provinsi Jambi.

2. Diduga dana pihak ketiga terdapat hubungan positif terhadap penyaluran kredit bank umum di Provinsi Jambi.

\section{METODE}

Metode yang digunakan dalam penulisan ini adalah riset kepustakaan (library research). Riset kepustakaan ini dilakukan dengan mempelajari teoriteori dan informasi yang berasal dari kepustakaan, laporan-laporan, artikel-artikel yang berhubungan dengan penelitian ini untuk memperoleh landasan teori dan informasi yang diinginkan untuk penelitian ini. Data diolah dengan bantuan software SPSS seri 21.0. selama periode tahun 2004-2015. Pengujian hipotesis pertama dilakukan dengan menggunakan model analisis regresi variabel independent terhadap variabel dependent. Dimana dalam penelitian ini, suku bunga, jumlah bank dan pertumbuhan ekonomi sebagai variabel independent (variabel bebas), akan dianalisis pengaruhnya terhadap Dana Pihak Ketiga (DPK) sebagai variabel dependent (variabel terikat).

Model persamaan regresi dalam penelitian ini dengan spesifikasi model dasar sebagai berikut :

$\mathrm{DPK}_{\mathrm{t}}=\beta_{0 t}+\beta_{1} \mathrm{SB}_{\mathrm{t}}+\boldsymbol{\beta}_{2} \mathrm{JB}_{\mathrm{t}}+\boldsymbol{\beta}_{3} \mathrm{PE}_{\mathrm{t}}+\mathrm{e}_{\mathrm{t}}$,

Keterangan:

DPK = Dana Pihak Ketiga Bank Umum (Miliar Rupiah); SB = Suku Bunga Bank Umum (persen); JB = Jumlah Bank (Unit); PE = Pertumbuhan Ekonomi (Persen); $\beta_{0}=$ Konstanta; $\beta 1 \beta 2 \beta 3=$ koefisien regresi untuk masing-masing variabel bebas; $\mathrm{e}=$ standar error; dan $\mathrm{t}=$ waktu

Pengujian hipotesis kedua untuk melihat hubungan dana pihak ketiga terhadap kredit bank umum Provinsi Jambi secara umum, menggunakan uji korelasi sederhana Pearson (Product Moment Coefficient of Correlation) dengan formulasi sebagaimana diungkapkan oleh Siagian dan Sugiarto (2000) dengan formulasi sebagai berikut :

$$
r_{i}=\frac{n \sum x_{i} y-\sum x_{i} \sum y}{\sqrt{\left(n \sum x_{i}^{2}-\left(\sum x_{i}\right)^{2}\right)\left(n \sum y^{2}-\left(\sum y\right)^{2}\right)}}
$$


Dimana $: r_{i}=$ nilai korelasi antara $x_{i}$ dengan $y ; n=$ jumlah periode; $x_{i}=$ Dana Pihak Ketiga (Rp); dan y = Kenaikan Kredit Bank Umum (Rp)

Besarnya koefisien korelasi ( $r$ ) antara dua buah variabel ( $\mathrm{Y}$ dan $\mathrm{X}$ ) adalah nol sampai dengan \pm 1 . Apabila dua buah variabel ( $Y$ dan $X$ ) mempunyai nilai $r$ $=0$ berarti variabel-variabel tersebut tidak ada hubungan. Apabila variabelvariabel itu mempunyai $r= \pm 1$, maka kedua variabel tersebut mempunyai hubungan yang sempurna. Adapun interpretasi tingkat keeratan hubungan antara variabel X dengan Y (variabel bebas dengan variabel terikat), digunakan tabel interpretasi koefisien korelasi dalam Sugiyono (2000) sebagai berikut:

\section{Tabel 1}

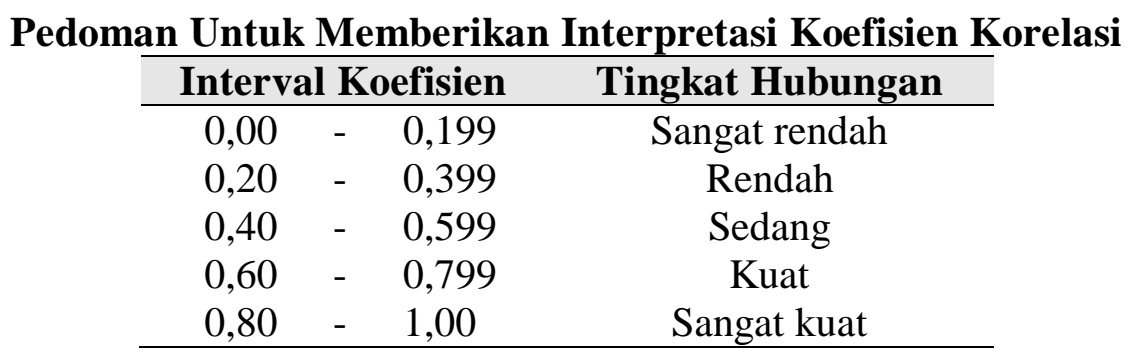

\section{Operasional Variabel}

Operasional variabel adalah suatu definisi yang diberikan kepada suatu variabel atau konstruk dengan cara memberikan arti atau menspesifiikasikan kegiatan, ataupun memberikan suatu operasional yang diperlukan untuk mengukur konstruk atau variabel tersebut. Sebagai panduan untuk melakukan penelitian dan dalam rangka pengujian hipotesis yang diajukan, maka perlu dikemukakan definisi variabel yang digunakan.

1. Dana Pihak Ketiga, adalah dana simpanan masyarakat dalam bentuk giro, tabungan dan deposito yang bersumber dari masyarakat untuk menyimpan dananya di bank. Satuan hitung untuk variabel belanja daerah adalah juta rupiah di Provinsi Jambi.

2. Kredit Bank Umum diukur melalui total kredit yang disalurkan di bank umum setiap tahunnya diukur dalam rupiah di Provinsi Jambi.

3. Suku Bunga adalah surat berharga yang diterbitkan Bank Indonesia sebagai utang jangka pendek dengan sistem diskonto dalam periode satu tahun anggaran yang dihitung dalam persentase.

4. Jumlah Bank adalah jumlah atau banyaknya tempat untuk menghipun dan menyalurkan kredit setiap tahunnya dalam satuan unit di Provinsi Jambi

5. Pertumbuhan Ekonomi adalah kenaikan kapasitas dalam jangka panjang dari negara yang bersangkutan untuk menyediakan berbagai barang ekonomi kepada penduduknya yang ditentukan oleh adanya kemajuan atau penyesuaian teknologi, institusional (kelembagaan), dan ideologis terhadap berbagai tuntutan keadaan yang ada yang diukur dalam persen selama periode kurun waktu satu tahun di Provinsi Jambi.

\section{HASIL}

Sesuai dengan metode penelitian untuk melihat faktor-faktor yang mempengaruhi dana pihak ketiga, maka perlu dilakukan analisis secara kuantitatif untuk melihat seberapa besar pengaruh suku bunga bank, jumlah bank dan pertumbuhan ekonomi terhadap dana pihak ketiga, dengan pengujian model 
kuantitatif menggunakan Metode Linier Berganda, melalui program SPSS versi 21.0, dimana hasil Hipotesis pengujian model Linier Berganda dapat dilihat sebagai berikut :

Tabel 2

Koefisiens

\begin{tabular}{|c|c|c|c|c|c|}
\hline \multirow[t]{2}{*}{ Model } & \multicolumn{2}{|c|}{ Unstandardized Coefficients } & \multirow{2}{*}{$\begin{array}{c}\text { Standardized } \\
\text { Coefficients } \\
\text { Beta } \\
\end{array}$} & \multirow[t]{2}{*}{$\mathrm{T}$} & \multirow[t]{2}{*}{ Sig. } \\
\hline & B & Std. Error & & & \\
\hline (Constant) & 6,258 & ,089 & & 70,238 & ,000 \\
\hline SB &,- 008 &, 005 &,- 071 & $-1,474$ &, 179 \\
\hline $\mathrm{JB}$ &, 016 & ,001 & ,905 & 19,146 &, 000 \\
\hline PE &, 045 & 009 & ,229 & 5,188 & ,001 \\
\hline
\end{tabular}

Sumber: Output SPSS

$\mathrm{DPK}=6,258-0,008 \mathrm{SB}+0,016 \mathrm{JB}+0,045 \mathrm{PE}+\mathrm{e}$

Dari persamaan dapat diintepretasikan dalam pembahasan dan hasil sebagai berikut :

1. Angka constant $\left(\beta_{0}\right)$ sebesar 6,258 memberi arti bahwa tanpa andanya variabel suku bunga bank, jumlah bank dan pertumbuhan ekonomi (dianggap konstan) atau sama dengan nol, maka dana pihak ketiga akan naik sebesar 6,258 satuan miliar rupiah.

2. angka koefisien regresi SB $\left(\beta_{1}\right)$ sebesar $-0,008$ memberi arti bahwa jika suku bunga bank naik sebesar 1 satuan persen maka akan menurunkan dana pihak ketiga sebesar 0,008 satuan miliar rupiah.

3. Angka koefisien regresi JB $\left(\beta_{2}\right)$ sebesar 0,016 memberi arti bahwa jika jumlah bank naik sebesar 1 satuan unit maka akan menaikkan dana pihak ketiga sebesar 0,016 satuan miliar rupiah.

4. Angka koefisien regresi PE $\left(\beta_{2}\right)$ sebesar 0,045 memberi arti bahwa jika pertumbuhan ekonomi naik sebesar 1 satuan persen maka akan menaikkan dana pihak ketiga sebesar 0,045 satuan miliar rupiah.

\section{Uji Hipotesis}

\section{Uji Parsial (Uji-t)}

Uji Parsial pada $\alpha=5 \%$ atau $<0,05$ dengan uji dua arah dan $\mathrm{df}=9$ (n $=$ 12 - 3 (variabel bebas) didapat : $t_{\text {tabel }}=2,262$, Maka $t$ hitung untuk variabel :

- Suku Bunga $(\mathrm{SB})=1,474<\mathrm{t}$ tabel $=2,262$, artinya penelitian ini menerima $\mathrm{H}_{0}$ dan menolak $\mathrm{H}_{\mathrm{a}}$ artinya suku bunga bank berpengaruh negatif dan tidak signifikan terhadap dana pihak ketiga Provinsi Jambi.

- Jumlah Bank $(\mathrm{JB})=19,146>\mathrm{t}_{\text {tabel }}=2,262$, artinya penelitian ini menolak $\mathrm{H}_{0}$ dan menerima $\mathrm{H}_{\mathrm{a}}$ artinya jumlah bank berpengaruh positif dan signifikan terhadap peningkatan dana pihak ketiga Provinsi Jambi.

- Pertumbuhan Ekonomi $(\mathrm{PE})=5,188>\mathrm{t}$ tabel $=2,262$, artinya penelitian ini menolak $\mathrm{H}_{0}$ dan menerima $\mathrm{H}_{\mathrm{a}}$ artinya pertumbuhan ekonomi berpengaruh positif dan signifikan terhadap peningkatan dana pihak ketiga Provinsi Jambi. 


\section{Uji Simultan (Uji-F)}

Pada $\alpha=5 \%$ atau $<0,05$ dengan uji dua arah dan $\mathrm{df}=8(\mathrm{n}=12-4(3$ variabel bebas dan 1 variabel tidak bebas) didapat : $\mathrm{F}$ tabel $=4,46$, maka $\mathrm{F}$ hitung $177,579>\mathrm{F}$ tabel $=4,46$, artinya dalam penelitian ini menolak $\mathrm{H}_{0}$ dan menerima $\mathrm{H}_{\mathrm{a}}$, artinya bahwa secara bersama-sama variabel suku bunga bank (SB), jumlah bank (JB) dan pertumbuhan ekonomi (PE) berpengaruh signifikan terhadap naik turunnya dana pihak ketiga (DPK) di Provinsi Jambi selama periode 2004 sampai dengan 2015.

Tabel 3

Anova

\begin{tabular}{|c|c|c|c|c|c|}
\hline Model & Sum of Squares & df & Mean Square & $\mathrm{F}$ & Sig. \\
\hline Regression &, 537 & 3 &, 179 & 177,579 &, $000^{\mathrm{b}}$ \\
\hline Residual & ,008 & 8 &, 001 & & \\
\hline Total &, 545 & 11 & & & \\
\hline
\end{tabular}

Sumber: Output SPSS

Koefisien Determinasi (Signifikansi R-Squared)

Tabel 4

Summary

\begin{tabular}{|l|r|r|r|r|}
\hline Model & R & R Square & Adjusted R Square & Std. Error of the Estimate \\
\hline 1 &, $993^{\mathrm{a}}$ &, 985 &, 980 &, 03174 \\
\hline
\end{tabular}

Sumber: Output SPSS

Hasil perhitungan R- squared yang ditunjukkan pada persamaan diatas diperoleh nilai $\mathrm{R}$ Square $=0,985$ atau $0,985 \times 100=98,50 \%$ (Angka koefisien determinasi dapat diartikan besarnya suku bunga bank, jumlah bank dan pertumbuhan ekonomi mampu mempengaruhi perubahan (naik atau turun) dana pihak ketiga Provinsi Jambi sebesar 98,50 \% sedangkan sisanya sebesar 1,50\% ditentukan oleh variabel lain diluar persamaan atau selain suku bunga bank, jumlah bank dan pertumbuhan ekonomi.

\section{Hubungan Dana Pihak Ketiga Terhadap Penyaluran Kredit Bank Umum}

Analisa perumusan masalah yang kedua digunakan dalam pengujian model kuantitatif dengan menggunakan metode korelasi pearson (Product Moment Coefficient of Correlation) melalui program SPSS versi 21.0 akan dihubungkan dana pihak ketiga terhadap penyaluran kredit bank umum, dimana hasil dapat dilihat sebagai berikut :

Tabel 5

Korelasi Pearson (Product Moment Coefficient of Correlation)

\begin{tabular}{|rl|r|r|}
\hline & & \multicolumn{1}{|c|}{ DPK } & \multicolumn{1}{|c|}{ KBU } \\
\hline \multirow{3}{*}{ DPK } & Pearson Correlation & 1 &, $994^{* * *}$ \\
& Sig. (2-tailed) & &, 000 \\
KBU & N & 12 & 12 \\
& Pearson Correlation &, $994^{* * *}$ & 1 \\
\hline
\end{tabular}




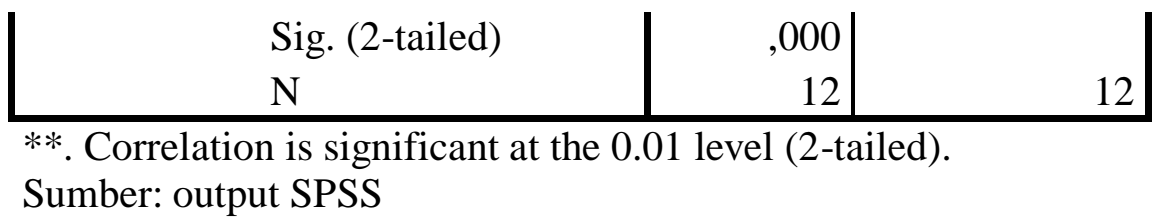

Hasil korelasi diatas maka di peroleh koefisien korelasi $\left(r_{x y}\right)$ sebesar 0,994 yang mana $r=0,994$ atau $0,994 \times 100=99,40 \%$ (angka korelasi ini memberi arti bahwa dana pihak ketiga mempunyai hubungan sangat kuat dengan penyaluran kredit bank umum Provinsi Jambi sebesar 99,40\%.

\section{SIMPULAN}

Kesimpulan hasil penelitian ini, diantaranya adalah sebagai berikut:

1. Dari hasil pembahasan penelitian pertama maka dapat disimpulkan bahwa suku bunga bank berpengaruh negatif dan tidak signifikan terhadap dana pihak ketiga Provinsi Jambi, sedangkan jumlah bank dan pertumbuhan ekonomi berpengaruh signifikan terhadap dana pihak ketiga Provinsi Jambi selama periode tahun 2004-2015 dengan R-square 99,3\%.

2. Hubungan antara dana pihak ketiga dengan penyaluran kredit bank sangat kuat dengan nilai korelasi sebesar 0,994 x $100 \%=99,40 \%$.

\section{DAFTAR PUSTAKA}

Adisetiawan, R., 2012, Faktor-faktor Keuangan yang dapat dapat Memprediksi

Kebangkrutan Suatu Bank dengan Metode Logistic Regression, Eksis:

Jurnal Ekonomi dan Bisnis, 3(1): 57-72

Adisasmita, Rahardjo. 2013. Teori-Teori Pembangunan Ekonomi. Yogyakarta

Anonim 1998, Undang-undang Nomor 10 Tahun 1998, Tentang Perbankan Rineka Cipta, Jakarta.

Arsyad, Lincolin. 2010. Ekonomi Pembangunan. Edisi Kelima. UPP STIM YKPN : Yogyakarta.

Budisantoso, T dan Sigit. 2006. Bank dan Lembaga Keuangan Lain. Edisi 2. Jakarta: Salemba Empat.

Boediono. 2009. Teori Pertumbuhan Ekonomi. Yogyakarta: BPFE Yogyakarta

Darmawan, Indra. 2007. Prilaku Tabungan Masyarakat Antar Daerah Di

Indonesia. Artikel diakses tanggal 28 Oktober 2016, http://indradarmawanusd.wordpress.com.

Hardi, Marisa. 2012. "Pengaruh Dana Pihak Ketiga (DPK) Dan Biaya Operasional Pendapatan Operasional (BOPO) Terhadap Return On Asset (ROA) (Studi Kasus Pada Bank Umum Swasta Nasional Devisa Yang Terdaftar Di BEI).” (13).

Hasibuan, Melayu SP. 2005. Dasar-dasar Perbankan. Jakarta: PT. Bumi Aksara.

Kajian Ekonomi Regional, Ekonomi dan keuangan Provinsi Jambi. Tahun 20072014.

Kasmir. S.E., M.M. 2002. Dasar-Dasar Perbankan. Jakarta: PT. Raja Grafindo Persada.

Kasmir. S.E., M.M. 2010. Bank dan Lembaga Keuangan Lainnya. Jakarta: PT. Raja Grafindo Persada.

Kuncoro Mudrajad dan Shardjono, 2011, Manajemen Perbankan, BPFE, Yogyakarta. 
Mardiasmo, 2004, Otonomi dan Manajemen Keuangan Daerah, Penerbit Andi, Yogyakarta.

Mudrajad Kuncoro. 2004. Otonomi Dan Pembanguan Daerah, Reformasi, Perencanaan, Strategi, Dan Peluang, Jakarta: Penerbit Erlangga.

Parera, J.D, 2004. Bank Indonesia, Bank Sentral Republik Indonesia, Suatu Pengantar, Penerbit-Pusat Pendidikan dan Studi Kebanksentralan (PPSK) Bank Indonesia, Jakarta.

Rihlah. 2010. Analisis Pengaruh Pertimbuhan Earnings Assets dan Pertumbuhan Dana Pihak Ketiga Terhadap Kinerja Operasional (Rasio BOPO) Pada Bank Umum Swasta Nasional Devisa. Skripsi S1, Fakultas Ekonomi Dan Bisnis Universitas Islam Negeri Syarif Hidayatullah.

Ryan Kiryanto. 2007. Langkah Terobosan Ekspansi Kredit. Jurnal Hukum Bisnis

Sastradipoera, komaruddin, 2004. Strategi Manajemen Bisnis Perbankan: Konsep dan Inplementasi Untuk Bersaing, Penerbit Kappa Sigma, Bandung.

Sukirno, Sadono. 2000. Ekonomi Pembangunan Proses, Masalah dan Dasar Kebijakan Pembangunan. UI-Press. Jakarta.

Sadono Sukirno, 2006. Ekonomi Pembangunan Proses Masalah dan Dasar Kebijakan, Cetakan Ketiga, Penerbit Kencana, Jakarta.

Samuelson, Paul A dan Nordhas, William D, 2001, Ilmu Makro Ekonomi. Jakarta. PT. Media Edukasi.

Taswan. 2006. Akuntansi Perbankan Transaksi dalam Valuta Rupiah. UPP AMP YKPN, Yogyakarta.

Thomas Suyatno, dkk. 2003. Dasar-dasar Perkreditan. Jakarta: PT. Gramedia Pustaka Utama.

Winoto, Danu. 2009. Analisis Pengaruh Penanaman Modal Asing, Penanaman Modal Dalam Negeri, Ekspor Total dan Kredit Perbankan Terhadap Pertumbuhan Ekonomi (Tahun 1970-2005). Skripsi. Surakarta : Fakultas Ekonomi Jurusan Ekonomi Pembangunan Universitas Sebelas Maret. 